
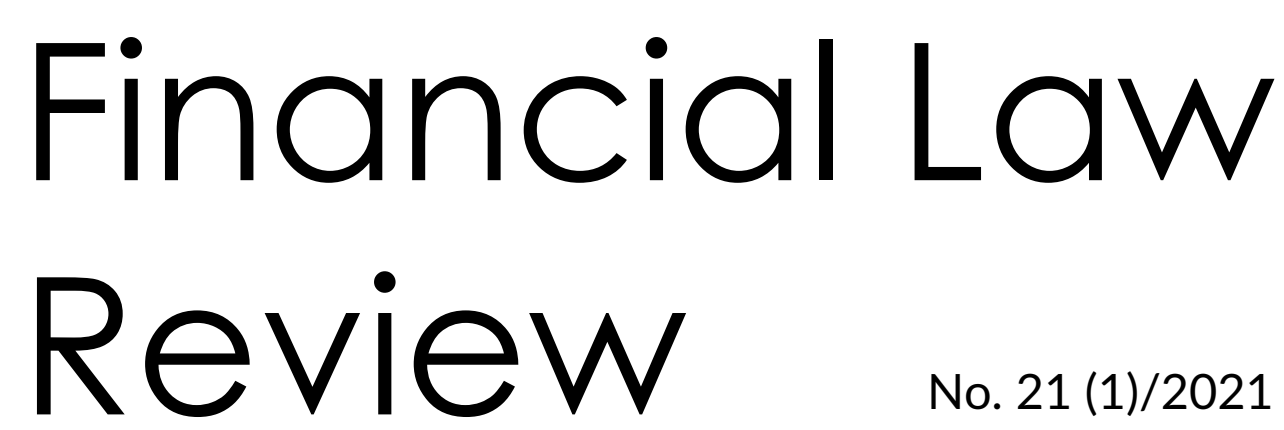

No. $21(1) / 2021$

UNIVERSITY OF GDAŃSK • MASARYK UNIVERSITY • PAVEL JOZEF ŠAFÁRIK UNIVERSITY • UNIVERSITY OF VORONEZH

http://www.ejournals.eu/FLR

EKATERINA TARHOVA*

\title{
VAT SPLIT PAYMENT - A TRICKY MATTER OF AIMING AT THE BEST DESIGN AND COMBINATION
}

\begin{abstract}
The article is an attempt to analyze the model of the split payment of VAT by comparing the experience of Republic of Bulgaria acquired prior to its accession to the EU with its modern day application in the EU by the Republics of Italy, Romania and Poland. The purpose is to contribute to the better understanding of this model, to draw the necessary conclusions from its implementation and use, and to understand its potential in the framework of the definitive VAT system - all this to the service of tax experts, policy makers and businesses.
\end{abstract}

Key words: VAT, method of payment, split payment, design, combinations, past and future.

JEL Classification: K34

\section{Introduction}

The interest of this article is twofold. First, it is an attempt to analyze the VAT split payment model and compare its implementation among various countries such as Bulgaria

* Tarhova Ekaterina - chief expert in Indirect Taxation Department within the Tax Policy Directorate, Ministry of Finance of Republic of Bulgaria. The author specializes in Value Added Tax and related procedural issues, as well as on matters regarding the protection of human rights in the taxation field. She has acquired her professional experience in the public and private sectors, in the national and EU context. She is a Head of Delegation of the VAT Committee attached to the European Commission. Contact email: e.tarhova@minfin.bg. 
(in its pre-EU accession period) and Poland, Romania and Italy, as present day EU Member States, in order to help policy makers and entrepreneurs to better understand and decide on the adoption and use of this model. It is also an endeavor to form a conclusion based on empirical evidence and using the logical, comparative and historical methods (nonexhaustively listed) on the potential of the split payment as a VAT collection tool within the framework of the future definitive EU VAT system. The main scientific tools works referred to in this article are the 2017 Deloitte Report "Analysis of the impact of the split payment mechanism as an alternative VAT collection method", the study of Konstantin Pashev "Countering Organized VAT Fraud in Enlarged Europe. Lessons from Bulgaria", the Special Report of Professor Robert Conrad on the Bulgarian VAT Account System, etc. The graphs and data shown in the present article stem from official statistics reported and published yearly by the Ministry of Finance of Republic of Bulgaria.

In 2010, or after approximately 40 years of application of the VAT system, the EU has undertaken its first efforts to reform it [COM(2010) 695, Commission Staff Working Document, SEC(2010) 1455]. After consulting all stakeholders and identifying its systematic failures, weaknesses, strengths and challenges ahead, the European Commission has carried out economics studies and initiated legislative steps towards a "simpler, more robust and efficient VAT system tailored to the single market" [Communication to the European Parliament, the Council and the European Economic and Social Committee on the future of VAT]. These efforts resulted in the two main sets of proposed rules: 1) a legislative package proposal containing four "quick fixes" to the current VAT system presented in 2017 - it has already been adopted by Council [VAT: Council adopts short-term fixes to current EU system], and 2) a proposal for a Directive containing the main legal corner stones of the future definitive VAT system and detailed technical arrangements for its application tabled for adoption by the Council of the EU in 2018 [European Commission, Taxation and Customs Union, Legislation].

In this context, the split payment model for VAT collection was subject to a special economic study ordered by the Commission but due to the non categorical conclusions of the study this model was not initially selected to become part of the legislative proposals on the future of VAT (Analysis of the impact of the split payment mechanism as an alternative VAT collection method, Final Report, Deloitte, December 2017, p. 202- 204). However, during the negotiations in the Council of the EU of the draft Directive on the technical arrangements for definitive VAT system [Proposal for a Council Directive amending Directive 2006/112/EC as regards the introduction of the detailed technical measures for the operation of the definitive VAT system for the taxation of trade between 
Member States, $\operatorname{COM(2018)} 329$ final, 2018/0164 (CNS)] and under the pressure of the European Parliament for swift reform of the tax and decreasing the VAT Gap [European Parliament resolution of 26 March 2019 on financial crimes, tax evasion and tax avoidance (2018/2121(INI)) - point 3], many EU countries assented to analyse it in combination with other measures such as the restriction of the right for input VAT deduction of the customer, or the joint and several liability of the customer [ECOFIN Report to the European Council from November 23, 2018].

As part of its enquiries to find a VAT collection system suitable for the VAT definitive system, the European Commission has in the past published a Study on the feasibility of alternative methods for improving and simplifying the collection of VAT [Study on the feasibility of alternative methods for improving and simplifying the collection of VAT through the means of modern technologies and/or financial intermediaries, PwC, 20 September 2010] which analyses 4 different VAT collection methods (that could be combined) selected as potentially suitable for a future definitive VAT system among 14 others in the light of the OECD criteria for tax systems:

1. Split payment model;

2. Central VAT monitoring database mode (push method)

3. Data warehouse model (pull method)

4. Certified taxable person.

With regards to the split payment model, the study mentioned earlier specially dedicated to it shows that both, from a theoretical and practical point of view, the split payment model can have many various design features, legal and digital environment and supporting measures such as:

- $\quad$ split agent - could be an intermediary (bank or credit and debit card companies), the supplier or customer even if he is not the tax debtor (e.g.: only large taxable persons in El Salvador, Honduras, exporters in Guatemala);

- $\quad$ transaction threshold - the split payment could be mandatory for transactions above certain monetary threshold;

- VAT amount of the split $-100 \%$ of the VAT amount could be split or lesser percentage (e.g.: 1 \% El Salvador, $30 \%$, 70\% Ecuador or 75\% Venezuela);

- $\quad$ automated or manual;

- $\quad$ applied to domestic supplies only or to all supplies;

- $\quad$ optional or compulsory;

- $\quad$ general or sectorial; 
- $\quad$ requiring an approval or freely allowed;

- operated via a tax office's account or a special (blocked) account of the supplier;

- $\quad$ applicable to B2B (Bulgaria, Poland), B2C or B2G (Italy) transactions;

- $\quad$ different incentives such as accelerated VAT refunds;

- information flows (important if an intermediary splitting agent is used) separate withholding VAT returns, special references on the invoice (Latin America) or e-invoicing (Italy, Azerbaijan).

\section{The Bulgarian experience with split payment}

The split payment in Bulgaria was in force for four years during the pre-EU accession period of the country, from 2003 to 2007 and it was optional during the first year. It was called "VAT account" as it operated as a special "closed" or "blocked" bank VAT account which had to be used for taxable transactions above 5000 leva (or for payment of VAT over 1000 leva) between VAT registered taxable persons. This threshold corresponded to the upper ceiling for cash payment allowed under Bulgarian law. The objectives of the model were: 1) to become an additional tool for an accelerated and guaranteed VAT refund, 2) to fight against VAT fraud and evasion and 3) to provide the tax authorities with more information on companies' turnover.

The model was based on the voluntary intermediation of the commercial banks which if they chose to participate in it had to monitor and report to the tax authority on the transfers and balance on these accounts. Banks were free to choose whether they would impose fees on these accounts which could be a form of remuneration for them for participating in the new system. The participating banks and the VAT accounts were all made public via a web link of the tax authorities.

\subsection{Main features}

It was a bank account of a holder registered for VAT purposes. The bank which wished to open and operate such an account had to accept serving the account under the conditions of the VAT Regulations for Implementation of the VAT Act by declaring it in writing and submitting it to the Executive Director of the National Revenue Agency (NRA). Then, with the permission of the NRA the account could be opened and it was attributed a special number different from a typical bank accounts. 
In the contract with the bank the holder had to agree to provide the tax authorities with the full information on the amounts available in the account and on its financial transfers, unconditionally and on an unlimited basis. The banks had to fulfil similar obligations towards the NRA: inform it about the opening, closing of VAT accounts, their balances and transfer movements. On closing, all amounts available in the VAT account had to be transferred to the competent tax administration for further assessment.

The split payment was not automatic - the taxable person was responsible for using it when the respective conditions were fulfilled. On the other side, the tax documents themselves emitted by the parties to a taxable transaction did not have to contain any special references to the use of the VAT account.

\subsection{Reliefs and incentives}

The VAT account system offered the following reliefs and incentives to the taxable persons:

1. Absolute exemption from the joint and several liability for the customer using a VAT account (this liability was very different from the present day EU concept with much less accent on the rights of the taxable persons) - the use of the VAT account for the payment of VAT due for a given supply resulted in an unconditional right of deduction of VAT for the client of this taxable supply even if his VAT registered supplier has not fulfilled its obligation to pay VAT to the State budget.;

2. Accelerated VAT refund - refund in 45 days instead of 3 months under the general procedure.;

3. VAT refund granted even if a tax audit is ordered. This relief was conditioned by a precise threshold indicating the intensity of use of the bank account: more than $80 \%$ of the VAT incurred by the taxable person (including on imports) had to be paid via a VAT account.;

4. Non-suspension of the deadlines for VAT refund in cases of lack of proper accounting, non-submission or lack of compulsory documents required by law, etc. (where suspension was normally applied). This relief was subject to the same $80 \%$ intensity of use threshold.

The infringement of the obligations to open and use a VAT account entailed administrative liability (fines to the amount close to the sanctions imposed for non-payment of VAT) but it did not result in the automatic refusal of the right of deduction. 


\subsection{Operation of the account}

The account could be used only for VAT payments. Possible transfers of money included:

- transfers from VAT accounts of other holders or from other VAT accounts of the same holder;

- transfers from regular bank accounts of the holder held in the same bank branch;

- transfers from regular bank accounts of budget-funded organizations which are not VAT registered;

- $\quad$ transfers to VAT accounts of other VAT registered persons;

- $\quad$ transfers to other VAT accounts of the same holder;

- $\quad$ transfers to the State budget for payments of VAT obligations.

No cash withdrawals or deposits were allowed with respect to the VAT accounts.

Refunds and release of sums available in the VAT account were possible in the following cases:

- $\quad$ payment of liabilities to the state budget other than VAT;

- $\quad$ undue VAT payment;

- $\quad$ payment of VAT obligation on grounds that were no longer valid.

In these cases, the person receiving the sums from a VAT account was compelled to return them back via the VAT account within 14 days from the day of receiving them or from the moment the grounds cease to exist. If they were not transferred back in the specified period the VAT obligations of the person that has made undue payments, assessed as a result of control checks or inspection, were collected and paid by the recipient within the amount of the undue payment.

Sums in the VAT account could also be released for the holder's profit/benefit: for payment of his VAT or other tax obligations, or subsequent refund.

Thus, even in case of undue VAT payment, the taxable person had first to transfer the undue payment to the State budget and, then, file for its refund. Such refund was conditioned by preliminary checks for outstanding tax obligations.

The VAT account could not be subject to coercive enforcement or serve as a collateral save for fulfilling the holder's VAT obligations. 


\subsection{Measures combined with this model}

1. Ceiling on payments in cash - money transfers amounts above BGN 5000 had to be paid via a bank transfer.

2. Joint and several liability - if there was a missing or non-compliant trader up the chain, the credit would be refused until the claimant is proven innocent in court.

3. Monthly sales and purchases' registers for all taxable transactions.

\subsection{Repeal - reasons}

The VAT account system was repealed for a number of reasons, such as the non-fulfilment of its objectives, the increase of the administrative burden for both, tax administration and business, the strong negative impact on taxable persons' cash flows, the county's accession to EU where this mode of VAT payment was largely unknown.

In the beginning of 2007 , the Bulgarian Parliament repealed the VAT account by motivating its decision with the additional costs related to the opening and maintenance of an additional bank account, the additional bank transfer documents and fees, the necessity of additional accounting services, the interests on bank credits granted to businesses that could not rely any more on the cash flow derived from VAT, etc. Further, the government detailed the reasons behind the pull out by the fact that this model is not familiar to the European companies and the means blocked by this mechanism amounts to approx. 600 millions of leva - a financial resource that enterprises could use as a working capital.

One of the main benefits of the VAT system - the more legally certain and faster refund of the tax became obsolete with a new amendment to the Bulgarian VAT Act allowing for unconditional VAT refund as long as the customer disposed of an invoice.

The disadvantages of the separate VAT payment model adopted by Bulgaria clearly outweighed the advantages. Most experts and representatives of the academic community collude around the conclusions outlined below.

\subsection{From the point of view of the tax authorities}

The system did not provide a solution to the problems associated with tax collection, fraud and tax evasion. Payment of VAT to another taxable person's account was not a sufficient guarantee for transferring VAT to the budget accounts, nor was the amount collected by the government actually payable. 
In essence, the system could be seen as effective against missing trader tax fraud, but it did not guarantee the prevention of many other tax avoidance schemes - such as false invoicing, bribery, fictitious exports, non-VAT registration or simple non-payment.

In addition, a new type of VAT fraud emerged linked specifically to the VAT account - the so-called "X-type" VAT fraud, a type of the "missing trader" fraud. According to a report from the General Taxation Directorate within the Ministry of Finance to the Parliamentary Commission on VAT Frauds as of the autumn of 2004 the VAT account provided new opportunities for fraudsters to evade VAT payments and drain the VAT account. Fraudsters benefited from the privilege of exemption from the application of joint and several liability when a VAT account was used. The organizer of the scheme exercised his right to deduct VAT despite the presence of a fraudulent taxable person along the chain, while at the same time, managing to empty the VAT account of the fraudulent taxable person [Pashev 2006].

Newly created tasks had to be performed by the tax authorities in order to properly manage and control the VAT account such as reviewing requests to open such accounts and maintaining a database of banking information, with the positive nuance that this information provided additional possibility for analyzing the risk. State resources were being scattered further with the increase of small time frame controls related to VAT accounts. Finally, the additional administrative burden did not cancel the necessity to enforce tax obligations that existed prior to the introduction of the VAT account.

The budgetary effect of the implementation of this type of split payment cannot be clearly distinguished and assessed since, as of January 1, 2003, the VAT registration threshold has been reduced (from BGN 75,000 to BGN 50,000 taxable turnover) resulting in about 13,000 newly registered taxable persons and in an increase of the VAT revenue effectively contributed to the State budget. However, as shown below, it was observed that with each passing year the number of persons holding more than one VAT account increased and the number of supplies below the mandatory threshold of BGN 5,000 for which the parties used a VAT account was constantly increasing in order for them to guarantee their right to deduct VAT.

Table 1. VAT Account statistics

\begin{tabular}{|l|c|c|c|c|}
\hline & 2002 & 2003 & 2004 & 2005 \\
\hline $\begin{array}{l}\text { VAT registered } \\
\text { persons (thous.) }\end{array}$ & 70485 & 84354 & 91236 & 97453 \\
\hline $\begin{array}{l}\text { Active VAT } \\
\text { accounts (thous.) }\end{array}$ & 80602 & 99019 & 110179 & 121427 \\
\hline
\end{tabular}

Source: Ministry of Finance of Republic of Bulgaria 
In 2004, almost $91 \%$ of the VAT applied by registered taxable persons was paid using VAT accounts, i.e. it was for only about $9 \%$ of the input tax that was at risk of not being recognized as a deductible tax due to a default of a participant (e.g. a fraudster) in the supply chain. It became increasingly difficult for tax authorities to deny the right to deduction of VAT - the ratio between denied deductible VAT and declared deductible VAT dropped from $1 \%$ in 2002 to $0.5 \%$ in 2005 .

\subsection{From the point of view of the taxable persons}

Undoubtedly, the main benefit of a VAT business account is the relative certainty that the tax credit due will be recognized in the presence of appropriate bank transfers to and from the taxable person's account.

Having a certain tax return guarantee is greater than the cost of complying with the system for large companies with computerized accounting systems and electronic banking. This is not the case for small and medium-sized businesses, for which in most cases the cost / benefit ratio is inversely proportional. In addition, the business as a whole emphasizes the technical inability to track the flow of goods and services along the value chain for the purpose of tracking the proper use of this tax payment model.

The main drawback for taxable persons is the retention of liquid cash on VAT accounts, as well as the increase in non-production costs related to increased paperwork and additional bank fees.

There is an incentive to manipulate this VAT payment instrument - splitting one transaction into several smaller ones (below the thresholds) to minimize the funds blocked in the VAT account or to consolidate transactions in order to reduce administrative costs. This leads to distortions of competition.

In conclusion, while the experience of the Republic of Bulgaria with a particular type of split VAT payment is relatively negative, it is useful in a larger European (even global) plan to examine the model more closely - both in theory and in practice taking into account the current harmonized taxation framework of the EU Member States and the progressive digitalization of VAT taxation and administration.

\section{The Romanian model}

In November 2017, Romania sent a request to the European Commission for derogation from the EU VAT rules in order to introduce the split payment of VAT in its legislation. The 
mechanism entered into force before the response of the Commission - from 1/01/2018, it applied as a mandatory method. However, later the same year, the European Commission found the Romanian model to be infringing the EU law and issued recommendations. Romania did not undertake to comply with them. Instead, it proceeded to repeal the split payment (at least as a mandatory method of VAT payment) with an emergency ordinance effective as 1/02/2020.

\subsection{Conditions for application}

The split payment mechanism applied to B2B transactions and was mandatory for taxable persons:

- $\quad$ with unpaid VAT liabilities up to certain thresholds set according to the type of the taxable person, i.e.: for tax arrears are above RON 15000 (approx. EUR 3 200) in case large taxpayers, above RON 10000 (around EUR 2 150) for medium taxpayers and above RON 5000 (around EUR 1080 EUR) for other taxpayers. The liabilities had to remain unpaid 60 working days after their due date; or

- who were subject to insolvency proceedings.

Other taxable persons could opt to apply the split payment mechanism in which case they were entitled to a reduction of $5 \%$ of the profit tax due (either corporate income tax or the micro-enterprises income tax).

\subsection{Repeal}

After analyzing the whole model, the European Commission found that this specific design of split payment mechanism did not ensure the equal treatment between taxable persons (within each category cited above), put a disproportional administrative burden on the customer, contained disproportionate sanctions and was contrary to the free movement of services [Communication from the Commission to the Council in accordance with Article 395 of Council Directive 2006/112/EC: 2-3].

The European Commission's analysis incited the repeal of the split payment by the Romanian legislator which impacted 18, 700 businesses that, previously, fell into the scope of the mandatory regime [Romania withdraws VAT split payment Feb 2020]. As of $2 / 02 / 2020$, the mechanism remains effective as an option only. 
The purpose of Romanian model was to effectively contribute to the country's efforts to reduce the VAT Gap and to fight against VAT fraud. However, because of the specifics of its design, the method was considered to infringe the EU law and, thus, it could neither fulfil its objectives nor fully prove its effectiveness. In fact, since the announcement of the repeal of the measure and its replacement by an option, less than $2 \%$ of the eligible taxable persons have applied for it. At least, from a business perspective, this shows a considerable increase of the compliance costs and an underlined disapproval of the model so designed.

\section{The Italian model}

In Italy, the split payment model is applicable since 1/1/2015. It will apply until 30/06/2020 based on a derogation from the EU VAT Directive 2006/112/EC permitted by the Council of the EU [Council Implementing Decisions (EU) 2015/1401 and 2017/784].

\subsection{Conditions for application}

The split payment is obligatory for B2G supplies, i.e. when the customers are public authorities (PA). The definition of "public authorities" is broad. It includes public hospitals, universities and chambers of commerce, irrespective of whether they act in commercial or institutional capacity. The split payment does not apply to non-economic public entities (research institutes, etc.).

This mechanism applies to all supplies of goods and services, except exempt, out of scope supplies, supplies certified by a receipt attesting no liability for vat) and supplies to which the reverse charge mechanism applies.

\subsection{Incentives}

The main incentive is the possibility for speedier (quarterly) and prioritized VAT refund provided that the output VAT is structurally lower than the input VAT.

\subsection{Application}

The customer spits the VAT to an allocated VAT bank account of the Treasury. The customer records the relevant invoices in its purchases ledgers. If the VAT on its purchases 
does not give rise to a right of deduction as per the general rules, the VAT amount must be transferred form the bank account of the Treasury to the Central Italian bank: on a one-off per each invoice, by the day, monthly.

There is strong link between the split payment and the electronic invoicing - all public authorities are registered to the SDI (Sistema di Interscambio), an IT system managed by the Italian Tax Agency, used to send and receive all invoices to public authorities, manage errors, messages and controls on format and information on the invoices. PA download from the SDI the invoices received on a regular basis (daily or more often for large organisations), register them in their ledgers and control them. If they are correct they are registered for payment. There is a special reference on the invoices that split payment applies.

PA have the obligation to inform electronically the tax authorities of all payments of electronic invoices carried out on a monthly basis (for reconciliation purposes) and, on 3 months basis, to publish the list of payments (made and received) carried out during that period.

\subsection{Measures combined with the split payment}

1. Sistema di Interscambio - mandatory from 1 January 2019. This is an IT system for real-time electronic invoice issue and reporting.

2. Esterometro - an IT system used by resident taxable persons to fulfil their obligation to report all their supplies from or to non-residents.

3. Stringent conditions for VAT refund - in principle, VAT credit can be reclaimed by refund or compensation. The VAT credit can be asked for refund only when the amount is higher than 2582,28 EUR and the VAT output is structurally lower than input VAT (specific business sectors). If lower than 2 582, 28 EUR VAT credit can be asked only in case of closing of business activity. If refund of VAT credit above 30000 EUR is asked and no bank guarantee is provided, such a refund can be obtained if the VAT credit is certified (by an audit team or by specialized individuals) and the company certifies also the fulfillment of certain capital and social security conditions required by law. If, considered "at risk", the taxable person must provide a guarantee.

VAT can be compensated either "vertically" (with other VAT debts) or "horizontally" (with other type of taxes, incl. social contributions for employees). 


\subsection{Results}

Official Italian statistics show that in 2015 , the split payment model was used by 40000 public authorities and 280000 suppliers, involving more than 300000 transactions formalized by invoices of approx. 10.6 EUR billion and resulting in 7.2 EUR millions of VAT paid.

The effect from using the split payment for the tax authorities can be summarized as follows: increase of the VAT revenue of 2.5 billion EUR for 2015 and 1 billion for 2016 (net VAT impact), as well as increase in the use of the VAT compensation mechanism. The net effect on the VAT Gap has been estimated as positive.

The effects for the business are less positive: worsening of the cash flow compensated to a certain extend by the possibility to file for VAT refund faster and with priority. To that must be added some one-off costs for training of the PA's personnel and for IT adaptations.

The Italian model is the only example in the EU for a partial application of the mechanism of split payment of VAT in a relatively safe environment - only applicable to B2 supplies. In addition to the stringent legal conditions for VAT refund the advanced stage of digitalization of the administration of VAT should be underlined which explains the relatively positive assessment of the application of the mechanism in that country. A similar phenomenon could potentially be observed in Poland in future.

\section{Polish model}

Introduced as an option in July 2018, the application of the split payment has become mandatory since $1 / 11 / 2019$. The basis for this is a derogation from the EU rules permitted by the Council of the EU [Council Implementing Decision (EU) 2019/310].

\subsection{Conditions for application}

After becoming mandatory, the split payment has the following scope - it applies to B2B supplies of sensitive goods and services such as waste, metals, construction works, electronics, etc. [The official website of the Polish Government containing a list of goods and services subject to the split payment of VAT], above 15000 PLN settled via bank transfer, exception made for the supplies subject to joint and several liability. Prior to $1 / 11 / 2019$, the same sensitive goods and services were subject to the reverse charge of 
VAT - as this mechanism proved unsuccessful it has been repealed and is, at present, replaced by the split payment.

\subsection{Incentives}

1. Exemption from the joint and several liability;

2. A shorter VAT refund period (25 days from filing the VAT return);

3. A reduction (although minimal) of the VAT payable by application of a specific formula.

\subsection{Application}

VAT accounts are automatically opened by the banks for all enterprises (subaccount to the existing one) in Polish currency and are of private nature.

When the split payment was optional, the customer decided whether to use the mechanism and proceeded to split the payment him/herself. Currently, the split is made by the banks after them receiving some transactional information (invoice number, VAT number of supplier, value of supply, amount of VAT). The release of the funds on a VAT account is possible upon request before the head of the competent tax office and after checks (max. 60 days). Such release is refused when there are arrears in VAT or justified concern that such arrears will occur.

\subsection{Measures accompanying}

It is remarkable that in the Polish split account model there are a few packages of measures designed to counter and fight VAT fraud that apply in parallel and have the potential to contribute considerably to the effectiveness of the mechanism.

1. Fuel Package (in force from 08/2016) - the right to sell fuels in Poland is restricted. It is granted only to entities registered there.;

2. Transport package (effective as of 04/2017) - it is an obligation to digitally register the transport of "sensitive goods" (fuel, alcohol and tobacco) combined with a monitoring system by GPS geo localisation of the road freight transport.;

3. Single Audit File (in force from 07/2016): since 1/01/2018, this is a standard by which accounting and tax relevant data is submitted on a mandatory basis by all non-exempt taxable persons to the tax authorities. 
4. STIR System and a "black list" of taxable persons (in force since 01/2018) - it is a system for cooperation with the banking sector. The banks' IT system designed to counter money laundering is used to also to detect potential VAT carousel frauds risks. If such a risk is detected, the bank the accounts blocks the respective bank account for $72 \mathrm{~h}$. and reports to its supervisory authority. It has been assessed as a very successful measure with effect from the first days. The "Black list" published by the Ministry of Finance contains potentially dangerous contractors who have been denied VAT registration or have been deregistered from the VAT system.

5. "White list" (effective in 2019): a list of trusted taxable persons whose VAT accounts are monitored by the tax authorities. In case of payments to the "nonwhite listed" banking accounts the deduction of the expense for income tax purposes is denied and, under the Polish VAT law, the purchaser is jointly and severally liable for paying the seller's output VAT. The list is published by the fiscal administration and updated daily. Also, as of 2018, the tax authorities are entitled to inform entrepreneurs of whether their contractors declared and pay taxes duly and on time.

6. The impact of the application of the split payment on VAT fraud levels, national budget, cash flows and administrative burden in Poland has not yet been assessed because of its recent entry into force. Despite the similarities with the Bulgarian system, against the background of the extremely massive and strict regulatory environment described above, the mechanism is expected to contribute positively to the successful counteraction of fraud with this VAT.

\section{Conclusions}

The split payment model has been and is applied in the past and present, in the EU and beyond. It gives rise to a strong scientific interest and is the subject of special economic studies [Analysis of the impact of the split payment mechanism as an alternative VAT collection method, Final Report, Deloitte, December 2017]. Although no unequivocal conclusions can be made from the theoretical research and the economic studies on the effectiveness of this VAT collection model, some useful lessons can be drawn from the experience of the Republic of Bulgaria, Italy and Poland on the successful and not so successful combinations between certain designs of the split payment and respective accompanying incentives, obligations, administrative measures, IT and legal environment. 
What comes as natural wisdom from those real life experiences is that for a meaningful application the split payment model should be combined with robust legal and IT solutions for preventing and curbing VAT fraud and that there could also be new unexplored possibilities such as the combination with other VAT collection models that could enhance the positive effects of both models. It is important to note that in 2018, during the negotiations in the Council of the EU on the future Definitive of System VAT and under the pressure from the European Parliament many EU Member States agreed to analyze the split payment mechanism in combination with other measures such as limitation of the right to deduct VAT or the joint and several liability of the client [European Parliament resolution of 26 March 2019 on financial crimes, tax evasion and tax avoidance (2018/2121(INI)].

Thus, Poland is becoming a pilot country in the EU with regards to the implementation of the split payment model in a variant involving a very wide scope of application. The eyes of the VAT world will be turned towards Poland because what lies before the whole European Union, and possibly before many other countries, is a very tricky and, somewhat, theoretical decision on the best combination of: the right design of the split payment model, the appropriate incentives, reporting obligations, legal and IT environment, and, even, a possible parallel application of an another VAT collection model, in order to ensure its best performance. 


\section{References}

Conrad, R.: Special Report on the Bulgarian VAT Account System,

Available at:

https://ime.bg/bg/articles/sistemata-na-dds-smetkata-w-bylgariq/, accessed at $15^{\text {th }}$ November 2019.

Ebrill, L., Keen, M., Bodin, J-P., Summers, V.: The Modern VAT, Washington D.C.: International Monetary Fund, 2001.

Pashev, K.: Countering Organized VAT Fraud in Enlarged Europe. Lessons from Bulgaria, Center for the Study of Democracy, Economic Studies (WP 0607/2 BG, July 2006)

Available at:

http://old.csd.bg/artShowbg.php?id=7715, accessed: 14 $4^{\text {th }}$ November 2019.

\section{Legal Acts}

Bulgaria's Value Added Tax Act (State Gazette No. 153/23.12.1998, effective 1.01.1999, amended and supplemented, SG No. 54/4.07.2006, repealed, SG No. 63/4.08.2006, effective as from the date of entry into force of the Treaty of Accession of the Republic of Bulgaria to the European Union - 1.01.2007).

Council Directive (EU) 2018/1910 of 4 December 2018 amending Directive 2006/112/EC as regards the harmonization and simplification of certain rules in the value added tax system for the taxation of trade between Member States, ST/12848/2018/COR/1, (OJ L 311, 7.12.2018, p. 3-7).

Council Implementing Decision (EU) 2015/1401 of 14 July 2015 (OJ L 217, 18.8.2015 p.7), prolonged and broadened by Council Implementing Decision (EU) 2017/784 of 25 April 2017 (OJ L 118, 6.45. 2017, p. 17-19).

Council Implementing Decision (EU) 2019/310 of 18/02/2019 authorizing Poland to introduce a special measure derogating from Article 226 of the VAT Directive (OJ L 51, 22.2.2019, p. 1927).

Italy's 2015 Stability Law of 23rd December 2014, (Law No 190 of 23 December 2014, Official Gazette, General Series No 300 of 29 December 2014 - Ordinary Supplement No 99, entered into force on 1 January 2015).

Poland's Act of August $9^{\text {th }} 2019$ amending the Act on Value Added Tax and Other Acts.

Proposal for a Council Directive amending Directive 2006/112/EC as regards the introduction of the detailed technical measures for the operation of the definitive VAT system for the taxation of trade between Member States (COM (2018) 329 final, Procedure 2018/0164/CNS).

Romania's Ordinance 23/2017 on the VAT split payment system (Official Gazette of 31 August 2017).

\section{Other Official Documents}

Analysis of the impact of the split payment mechanism as an alternative VAT collection method, Final Report, written by Deloitte, December 2017

Available at: https://ec.europa.eu/taxation_customs/sites/taxation/files/split_payment_report2017_en.pd accessed: $8^{\text {th }}$ October 2020.

Communication from the Commission to the Council on the Romanian request for introducing the VAT Split Payment in accordance with Article 395 of Council Directive 2006/112/EC of 13 November 2018, 14178/18 FISC 473 ECOFIN 1043

Available at:

https://data.consilium.europa.eu/doc/document/ST-14178-2018-INIT/en/pdf, accessed: $8^{\text {th }}$ October 2020.

Communication from the Commission to the European Parliament, the Council and the European Economic and Social Committee on the future of VAT, Towards a simpler, more robust and efficient VAT system tailored to the single market (COM (2011) 851 final, 6.12.2011)

Available at:

https://eur-lex.europa.eu/legal-content/EN/TXT/?uri=COM:2011:0851:FIN, accessed: $8^{\text {th }}$ October 2020. 
Commission Staff Working Document accompanying the Green Ppaper on the future of VAT "Towards a simpler, more robust and efficient VAT system", COM(2010) 695, Commission Staff Working Document, SEC(2010) 1455, 1.12.2010

Available at:

https://ec.europa.eu/taxation_customs/sites/taxation/files/resources/documents/common/ consultations/tax/future_vat/sec\%282010\%291455_en.pdf, accessed: $8^{\text {th }}$ October 2020.

ECOFIN Report to the European Council of November 23, 2018 ECOFIN on tax issues Endorsement

Available at:

http://data.consilium.europa.eu/doc/document/ST-14601-2018-INIT/en/pdf, accessed: $8^{\text {th }}$ October 2020.

European Parliament resolution of 26 March 2019 on financial crimes, tax evasion and tax avoidance (2018/2121(INI))

Available at:

https://www.europarl.europa.eu/doceo/document/A-8-2019-0170_EN.html, accessed: $8^{\text {th }}$ October 2020.

Report of February 2019 on Reducing the VAT Gap: lessons from Poland, the Polish Economic Institute

Available at:

http://pie.net.pl/wp-content/uploads/2019/02/Raport-LUKA-VAT-EN.pdf, $\quad$ accessed: $8^{\text {th }}$ October 2020.

Study on the feasibility of alternative methods for improving and simplifying the collection of VAT through the means of modern technologies and/or financial intermediaries, Final Report - 20 September 2010 (PwC)

Available at:

https://op.europa.eu/en/publication-detail/-/publication/e0d6a4f7-9ada-11e6-868c01aa75ed71a1/language-en/format-PDF/source-115112902, accessed: $8^{\text {th }}$ October 2020.

\section{Internet Resources}

The official website of the Polish Government containing a list of goods and services subject to the split payment of VAT

Available at:

https://www.gov.pl/attachment/b3e4d0a8-c44d-477c-bb79-fc635146cf6d, accessed: $12^{\text {th }}$ February 2020.

The official website of the European Commission, Taxation and Customs Union, Legislation Available at: https://ec.europa.eu/taxation_customs/legislation_en, accessed: 9 ${ }^{\text {th }}$ October 2019.

The official website of the Ministry of Finance of Republic of Bulgaria

Available at: https://www.minfin.bg/bg/240, accessed: $1^{\text {st }}$ November 2019.

The official website of the Bulgarian Revenue Agency

Available at:

https://nap.bg/document?id=232, accessed: $2^{\text {nd }}$ November 2019.

Romania withdraws VAT split payment Feb 2020

Available at: https://www.avalara.com/vatlive/en/vat-news/romania-withdraws-vat-splitpayment-feb-2020.html , accessed: $2^{\text {nd }}$ February 2020.

VAT split payment mechanism to become optional

Available at: https://www.bdo.global/en-gb/microsites/tax-newsletters/indirect-taxnews/issue-3-2019/romania-vat-split-payment-mechanism-to-become-optional, accessed: $3^{\text {rd }}$ February 2020.

VAT: Council adopts short-term fixes to current EU system

Available at:

https://www.consilium.europa.eu/en/press/press-releases/2018/12/04/vat-council-adoptsshort-term-fixes-to-current-eu-system/, accessed: $10^{\text {th }}$ October 2019. 